\title{
Evaluation of nerve procedures and FFMT in adult BPI - the Surabaya experience
}

\author{
Heri Suroto
}

From 10th Congress of the Asia-Pacific Federation of Societies of Surgery fo the Hand and the 6th Congress of Asia-Pacific Federation of Societies of Hand Therapists

Kuala Lumpur, Malaysia. 2-4 October 2014

\section{Purpose}

The purpose of this study was to describe our experience with various nerve and muscle procedures in traumatic adult brachial plexus injuries.

\section{Materials and methods}

Two hundred and nine $(\mathrm{n}=209)$ cases of adult brachial plexus injuries were treated in Surabaya from March 2005 to May 2014. Thirty seven cases treated in 2014 were excluded from this study.

\section{Results}

The number of operative cases of brachial plexus injury increase each year. Fifty nine percent of cases were managed in public hospitals and $41 \%$ in private hospitals. Most of the patients were males (86\%) and the rest were females (14\%). Brachial plexus injury was most prevalent between 21-30 years of age (37\%). Motor vehicle accident was the most frequent mode of injury (90\%). The right side was the most frequently affected side (77\%). The levels of injury were as follows: C5-6 postganglionic (24\%), C5-7 postganglionic (19\%), C8-T1 postganglionic (3\%), C5-T1 (54\%). In complete BPI, the combination of C5-7 postganglionic and C8-T1 preganglionic were present in $33 \%$ of cases. There were 2 types of surgical intervention: nerve procedure $(67 \%)$ and muscle procedure (33\%). Nerve transfer was the most frequently employed mode of nerve procedures (54\%, one third of which was either Oberlin's transfer or double fascicular nerve transfer). The most frequently performed muscle procedure was the free functioning muscle transfer (78\%).

Published: 19 May 2015

Department of Orthopaedics, Dr Soetomo General Hospital, 6-8, Surabaya, Indonesia

(0) 2015 Suroto; licensee BioMed Central Ltd. This is an Open Access article distributed under the terms of the Creative Commons Attribution License (http://creativecommons.org/licenses/by/4.0), which permits unrestricted use, distribution, and reproduction in any medium, provided the original work is properly cited. The Creative Commons Public Domain Dedication waiver (http:// creativecommons.org/publicdomain/zero/1.0/) applies to the data made available in this article, unless otherwise stated.
doi:10.1186/1753-6561-9-S3-A23

Cite this article as: Suroto: Evaluation of nerve procedures and FFMT in adult BPI - the Surabaya experience. BMC Proceedings 2015 9(Suppl 3): A23.

Submit your next manuscript to BioMed Central and take full advantage of:

- Convenient online submission

- Thorough peer review

- No space constraints or color figure charges

- Immediate publication on acceptance

- Inclusion in PubMed, CAS, Scopus and Google Scholar

- Research which is freely available for redistribution 